\title{
Hervormde hermeneutiese perspektiewe op Skrifverstaan en die Nuwe Testament
}

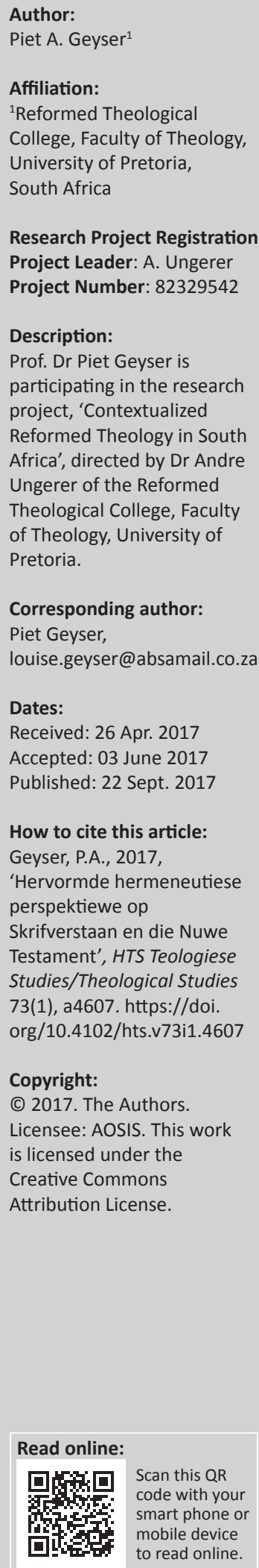

This article reflects on hermeneutics in the widest sense of the concept and not on the detailed technicalities from philosophical and other perspectives. Hermeneutics will be taken to refer to the whole act and process of understanding. It is done with special reference to how the understanding of Scripture and specifically the New Testament of theologians of the Netherdutch Reformed Church over the past seven decades, is reflected in the work in the HTS Theological Studies journal. It is clear that their approach to the understanding and concretisation of the message of the New Testament was one of greatest respect for Scripture. The basic tenet throughout was that the Word of God was to be found in the Bible. There was no assumption that Bible and Word of God were identified on one and the same level. Taking the Bible as literature seriously implied that the best scientific methods had to be found and implemented in this search for the meaning of the Word of God for the Church's message and practice in the world.

\section{Hermeneutiek as die hele proses hoe ons tot verstaan kom}

Hierdie artikel sou in die geheel daaraan gewy kon word om in al die fyner genuanseerde aspekte van die begrip hermeneutiek op te gaan. Dit sal geen oordrywing wees indien gestel word dat hierdie begrip oorvloedige aandag en beskrywing in die afgelope dekades ontvang het nie. Daarom sal ek vir die doel van hierdie artikel met 'n baie algemene aanduiding van die begrip hermeneutiek moet werk en al die ander filosofiese, filologiese en teologiese besprekings aan ander geleerdes - wat hieroor veel meer weet as ek - oorlaat. Vir die doel van hierdie artikel sal hermeneutiek verwys na die geheelproses van hoe ons tot verstaan van die Skrif kan kom en ook hoe hierdie verstaan in die totale kerklike verkondiging tereg kom.

Dit is reeds in die opdrag wat aan my gegee is duidelik dat die oogmerk met hierdie artikel is om hermeneutiek in verband met Skrifverstaan en uitleg, soos weerspieël in publikasies in die HTS Teologiese Studies sedert die ontstaan van die tydskrif in 1944, te ondersoek. Anders as wat dikwels in die verlede gedink is, sal hermeneutiek nie beperk word tot die beskrywing van eksegetiese metodes nie (die reëls vir eksegese). Dit gaan oor die hele proses van verstaan. En dan in die besonder oor die wyses waarop onder andere, in die Nederduitsch Hervormde Kerk van Afrika in die afgelope eeu geworstel is met die proses van verstaan en uitleg van die Nuwe Testament as deel van Heilige Skrif (Bybel).

Ons kan ook nie anders nie as om die uitgangspunt dat die Kerk die Skrif a-priories beskou as die skriftelike neerslag van die getuienis waarin die Woord van God te soek en te vind is, heelhartig te onderskryf. Hieruit is ook duidelik dat ons daarmee twee aspekte beklemtoon: die eerste is dat die Bybel as bron en norm vir alle kerklike getuienis erken en eerbiedig word; en tweedens, dat die Hervormde Kerk daarmee van meet af aan die standpunt gehuldig het dat ons juis op grond van eerbied vir hierdie bron krities daarmee moet omgaan. Bybel en Woord van God staan nie in 'n een tot een verhouding met mekaar nie. Dit bring mee dat hermeneutiese uitgangspunte die totale proses wat in Skrifbeskouing, -gebruik en uitleg ter sake is, impliseer. Dit gaan oor die verstaan van hierdie Boodskap soos dit in en deur die boeke van die Bybel oorgedra word en hoe die Boodskap in die Kerk ontvang word en dan ook weer diensbaar gemaak word vir die Kerk se leer en lewe in die wêreld. Hieroor kan ons saam besin deur met enkele penstrepe aan te dui hoe daar in die verlede en deur verskillende Hervormde teoloë daaraan uitdrukking gegee is dat ons krities, dit wil sê wetenskaplik, met die Skrif omgaan in ons eerlike en eerbiedige soeke na die verstaan van die boodskap van die Skrif. Verder word aangetoon hoe hierdie verstaan van die Woord van God, soos ons dit in die Skrif verneem, die geloof en lewe van mense van alle tye vorm en rig. Die ondersoek sal veral afgestem word op artikels wat oor die jare in die Hervormde Teologiese Studies (HTS) verskyn het en met behulp van die nuttige Argief-funksie, wat deesdae beskikbaar is vir die HTS, opgespoor kan word. 
Wanneer die tema van die hermeneutiek nagegaan word, blyk dit dat die teoloë vroeër nie baie teoretiese aandag gegee het aan teorieë en metodes nie. Dit is eintlik eers vanaf die tagtiger jare van die vorige eeu dat hierdie saak ernstig onder die loep geneem is. Tog blyk dit dat daar in die naïewe of intuïtiewe houding van die begin af in die omgang met die Skrif ' $n$ kritiese moment was. Dit is ' $n$ aanduiding dat Hervormde teoloë nog altyd 'n gelowige-kritiese houding ten opsigte van die Skrif en Skrifuitleg gehad het.

\section{Vroeë aanduidings van 'n kritiese houding}

'n Interessante verklaring word in 1944 uitgereik deur professore J.H. Greyvenstein en B. Gemser namens 'die vernaamste eksegetiese kragte van die Hervormde Kerk'. Hierin word verduidelik waarom hierdie geleerdes nie kon saamwerk aan die Bybel met Verklarende Aantekeninge nie. Greyvenstein (1944) stel dit soos volg:

... [D]ie voorgestelde grondslag van die Bybelverklaring het vir ons voorgekom in stryd te wees met die Reformatoriese standpunt. In die omsendbrief wat die grondslag en die doel uiteenset, is verklaar dat die Bybelverklaring sal moet 'gebore wees uit die Gereformeerde godsdienstige oortuigings van die volk', dat dit sal moet gee "n uiteensetting van die Gereformeerde verklaring van die Skrif'. Die grondslag sal wees 'die Gereformeerde Skrifverklaring'. In hierdie beleidsverklaring word die Skrif en Skrifverklaring diensbaar gemaak aan'n bepaaldeSkrifbeskouing, met ander woorde, Gods Woord aan menslike beskouings oor Gods Woord; selfs is die Skrifverklaring hier verlaag tot ' $n$ propagandamiddel vir 'n bepaalde beskouing oor die Skrif. Die vraag word in hierdie verklaring gevra: waar kry ons die reg om Woord en Gees te bind aan menings van konsilies of sinodes of 'Gereformeerde' of dan wel ongereformeerde belydenisskrifte? Op eg Kuyperiaanse, neo-Calvinistiese wyse het hulle in die verskillende kerke medewerkers wou versamel rondom die belydenisskrifte. Die Hervormde medewerkers het die versoek gerig dat elke medewerker self in wetenskaplike en leerstellige opsig verantwoordelik sal wees vir sy aandeel in die Bybelverklaring. (bl. 97)

Wat deur hierdie teoloë van die Hervormde Kerk as samevattende rede gegee is vir waarom hulle nie kon saamwerk met die projek nie, is die volgende:

Nou is ons deur die regte eerbied vir die Woord van God, die eg Reformatoriese standpunt insake die verhouding van Skrif, kerk en belydenis, die selfrespek van die Kerk insake sy trou aan die belydenis en van sy ampsdraers, insake die opregtheid van hulle ondertekening daarvan, asook deur die eis van 'n vrye, gesonde ontwikkeling van die wetenskaplike Skrifondersoek en Bybelverklaring (my beklemtoning. PAG), deur al hierdie vyf belangrike beginsels verbied om voor die wil van die redaksielede te buig. Ons staan liewer in die vryheid waarmee Christus ons vrygemaak het as om ons onder die juk van diensbaarheid aan menslike insettings te laat bring; ons is oortuig dat die Waarheid groot is en sal oorwin, en dat die Woord van God nie een van die staketsels ${ }^{1}$ waarmee mensewysheid en mense-oormoed meen om dit te moet steun en handhaaf, nodig het nie, ja dat dit hulle almal te skande sal maak. (Greyvenstein 1944:99)

1.Argaïese Afrikaans vir 'omheining', 'palisade'.
Hierdie verklaring is onderteken deur J.H. Greyvenstein, professor in 'Nieu Testamentiese Wetenskap vanweë die Ned. Hervormde Kerk aan die Universiteit van Pretoria', en B. Gemser, professor in Ou Testamentiese Wetenskap vanweë die Ned. Hervormde Kerk aan die Universiteit van Pretoria te Pretoria op 07 Maart 1944. Samewerking is verder bemoeilik deur die wantroue van die twee redakteurs van die voorgestelde projek van 'n verklarende Bybel, of die Hervormde medewerkers getrou sou wees aan die belydenis (kyk Greyvenstein 1944:98).

Ter wille van billikheid moet ons tog hier op die volgende verwikkeling let: Toe die Bybel met verklarende Aantekeninge in 1958 verskyn het - nadat die werk in alle erns in 1953 begin het, was daar wel Hervormde medewerkers en selfs redaksielede wat hieraan meegewerk het. Wat verander het van 1945 tot 1953 is moeilik om vas te stel. Die redaksie het as uitgangspunt toe gestel: 'Daarom is in ooreenstemming met die belydenis van die Hollands-Afrikaanse Kerke 'n behoudende en tegelyk wetenskaplik verantwoorde standpunt gehandhaaf' (Bybel met Verklarende Aantekeninge 1958).

Ek het redelik uitvoerig by hierdie artikel stilgestaan omdat ek van mening is dat ons hierin op 'n duidelike en ondubbelsinnige manier die riglyne vind vir 'n Hervormde hermeneutiek, dit wil sê die houding, gesindheid en werkwyse waarmee Hervormde teoloë van toe af tot vandag met die Heilige Skrif wil omgaan.

Een van die ander teoloë wat hom in die vroeë jare op 'n deurlopende grondslag besig gehou het met Skrifbeskouing en Skrifhantering was - toe nog - doktor F.J. van Zyl. Ons vind 'n samevatting en verwerking van 'n lesing voor die predikantevergadering met die tema 'Die Skrifbeskouing van Karl Barth', wat in die HTS 3 van 1944 verskyn het (Van Zyl 1944a). Hy het ook 'n reeks artikels hieroor in die jare 1969-1970 in Die Hervormer laat verskyn onder die opskrif 'Ken jy die Bybel'. Behalwe wat hy hieroor gepubliseer het, het sy hermeneutiese benadering en Skrifbeskouing in sy hele teologiebeoefening na vore gekom. Na my oordeel is hierdie werk van Van Zyl vir die teologiebeoefening in die Hervormde Kerk van onskatbare waarde, veral omdat dit die verwoording van ongeskrewe, ongeformuleerde teologiese uitgangspunte bevat wat in die teologiebeoefening van die Hervormde Kerk tot vandag toe sterk funksioneer. Uit bostaande is dit duidelik dat Van Zyl se gedagtes in 'n groot mate gevorm is deur die denke van Karl Barth. Een van sy uitgangspunte was die volgende standpunt (Van Zyl 1944b:6): 'Ons lees die Bybel omdat ons daarin die sprekende stem van God verneem. Daarom het die Bybel gesag. Daarom is hy die norm, die maatstaf van ons hele lewe'. Hierin kan die bekende Barthiaanse standpunt dat die Bybel die getuienis aangaande die Woord van God bevat, reeds gehoor word. Dit het ook meegebring dat die Bybel as 'n boek, of anders gestel, 'n biblioteek van boeke gelees word sonder om aan die Bybel as godsdienstige objektiewe voorwerp of 'n magiese 'teksmagasyn' te dink. Ons sou ook kon sê dat dit die weg berei het vir die standpunt wat later uitgekristaliseer het, naamlik dat daar reeds sedert die Reformasie ' $n$ verskil 
was tussen hermeneutica sacra en hermeneutica profana. Daarom is die Bybel meer en meer in sy historiese verband bestudeer as ' $n$ boek soos ander boeke. Vir Reformatoriese teologie is daar egter altyd wel die voorbehoud dat die Bybel die bron bly waarin die stem van God gehoor kan word. Omdat die Bybel as boek bestudeer word, het Van Zyl ook grondliggende vrae aan die orde gestel, naamlik: Waar kom hierdie boek vandaan? Hoe het dit onwikkel? Hoe is dit saamgestel? In watter opsig het dit as ' $n$ veelheid van manuskripte vir ons tot ' $n$ boek geword? Dit beteken dat kwessies soos die kanonvraag en tekskritiek in die benadering tot die Bybel reeds toe aan die orde gestel is. By Van Zyl (1944b; vgl. Brunner ([1938] 1963; kyk Geyser 1989:253-262) het die gesag van hierdie boek duidelik na vore gekom in die waarheidsvraag, maar dan die waarheid as ontmoeting. P.J. van der Merwe (1989:242) het in die huldigingsbundel, opgedra aan Van Zyl, sy bydrae soos volg raakgevat: 'In 'n tyd toe 'n breë prekritiese fundamentalistiese Skrifgebruik algemeen gangbaar was in die Afrikaanse kerke en teologie (veertiger jare), stel Van Zyl 'n Skrifbeskouing wat die moderne Bybelwetenskap in 'n groot mate geantisipeer en verdiskonteer het'.

Die kwessie oor kerk, belydenis en eksegese in die vroeë jare vra verdere toeligting. 'n Artikel van professor B.J. Engelbrecht met die titel 'Wat is die reg en die vryheid van die eksegeet?' het in 1986 in die Eenvormigheid? Vgl vorige gebruike van HTS verskyn. Hoewel die artikel eers in 1986 verskyn het, gaan dit terug na 'n advies wat in 1962 deur professor Engelbrecht uitgebring is. Die advies is geskryf in opdrag van die Algemene Kommissie na aanleiding van die klag wat teen die leer van professor A.S. Geyser ingebring is. Die rede daarvoor was kortliks dat professor Geyser aangevoel het dat dit ' $n$ Reformatoriese beginsel is dat die Skrif as norma normans bokant die kerklike belydenis as norma normata staan. Gevolglik word eksegete nie in hulle arbeid deur die kerklike belydenis beperk ten opsigte van die eksegetiese metode of die resultate van die eksegese nie. Dit gaan dus in hierdie advies wesenlik om die vraag oor die verhouding tussen kerklike belydenis en eksegese.

In sy betoog wys Engelbrecht op die verskillende benaderings van die Rooms-Katolieke Kerk en die Reformatoriese Kerke. Een van die kernpunte van hierdie verskil kan soos volg opgesom word (Engelbrecht 1986):

Die Heilige Skrif is vry van die binding aan die tradisionalisme van die Roomse Kerk. Die resultaat van Skrifondersoek staan nie vantevore al vas, gebind deur die gesag, tradisie en dogma van die kerk nie. Daar bestaan nie meer in dieselfde sin as by Rome 'n offisieel-kerklike eksegese nie. (bl. 488)

Oor die nodigheid en struktuur van eksegese word gestel dat eksegese nodig is vanweë die karakter van die Heilige Skrif. Die Bybel is geen towerboek wat kant en klaar uit die hemel geval het nie. Die Heilige Skrif is 'n menslike boek, al glo ons dat dit die Woord van God ook bevat. Die menslike aard van hierdie geskrifte is sodanig dat dit verstaan word as die Woord van God wat deur mense gehoor, neergeskryf en literêr bewerk is. Dit het dus as sodanig 'n geskiedenis. In die tweede plek word dit gelees deur mense in wie se geskiedenis dit 'n rol speel. Hierdie laaste opmerking, naamlik dat die Heilige Skrif deur mense gelees word, maak eksegese noodsaaklik. Uit die geskiedenis het dit geblyk dat mense nie die teks eners lees of verstaan nie. Daarom roep die teks altyd die uitleg daarvan ook op.

Hierdie opmerkings van Engelbrecht maak dit duidelik dat daar ' $n$ afstand is tussen die optekening en die woord of woorde wat oorspronklik deur die profeet of apostel gespreek is. Dit het ook alles afgespeel in ' $n$ bepaalde historiese situasie. Dit maak dit dus meteens duidelik dat daar ruimte is vir historiese en literêre kritiek wat ook later in hermeneutiese paradigmas ontwikkel het. Hiermee gaan saam dat daar ook 'n afstand is tussen die woord wat die profeet of apostel gehoor en gespreek het en 'die openbaring' self waaroor hulle praat. Al hierdie aspekte vra dus om 'n hermeneutiese benadering waarin bepaalde vrae aan die teks gestel word en waarop daar antwoorde gesoek word.

Die ander kant van hierdie aangeleentheid kom egter ook na vore in die artikel van Engelbrecht. Die eksegeet sal altyd ook bewus moet wees van die element van subjektiwiteit wat noodwendig na vore kom in die proses van interpretasie. Daarom kan die kerk ook vra dat, in die soeke na die uitleg en die samehang van een gedeelte met die res van die Bybel, die eksegeet ook op vorige dergelike eksegetiese samehange sal let. Dit word onder andere gevind in die kerklike dogma (kyk Engelbrecht 1986:497). Die kerklike dogma wil in die Protestantse milieu niks anders wees as kerklike eksegese oor die hoofpunte van die Christelike geloof nie. Dit bring dus mee dat daar ook binne die Protestantisme iets soos 'n'offisiële eksegese' kan wees, naamlik die dogma van die kerk. Alhoewel toegegee word dat hierdie kerklike leer of kerklike dogma net so subjektief en voorlopig kan wees as die eksegese van individuele eksegete, word daar tog aangedring dat beide eksegese en die leer oop moet wees vir hersiening en wysiging. Individuele eksegete moet egter onthou dat die kerklike dogma alleen deur die kerk gewysig kan word (by wyse van gravamina). Opsommend kan die gevolgtrekking dus gemaak word dat eksegete (wat net soos ander teoloë in diens van die kerk en prediking staan) tegelyk vryheid het en gebonde is (Engelbrecht 1986:500).

Die twee aspekte van die kwessie oor kerklike belydenis en Skrifverstaan is met mekaar verweef as deel van 'n teologiese hermeneutiek. Hierdie gesprek gaan steeds voort. Dit kom onder andere na vore in 'n artikel van professor G.M.M. Pelser (1985:339-350) met die titel 'Die verhouding Bybelse teologie en dogmatiese teologie'. Die besinning in hierdie artikel verteenwoordig 'n verfyning van die kwessie oor Bybelse eksegese en Bybelse teologie enersyds, en dogmatiese teologie andersyds. In 'n meer kritiese fase laat die denke van Pelser wel duidelik blyk dat hierdie twee kategorieë in die verlede te reglynig en simplisties hanteer is. Dit word duidelik dat dit vir die kerk in die verlede meer gegaan het oor die sogenaamde dicta probantia wat in die Bybel gevind moes word (dit wil sê tekste wat die leer kon regverdig) en wat dan aangebied is as Bybelse teologie, maar met die oog op 'n regverdiging van die kerklike dogma. Alhoewel die 
vraag na 'n Bybelse teologie so ver teruggaan as J.P. Gabler se professorale intreetrede op 31 Maart 1787 (Gabler 1831:179_ 198; kyk Boers 1979), het die kwessie oor Bybelse teologie nie weer gefigureer tot laat in die twintigste eeu nie. Daar is in jonger tye nie konsensus oor wat met 'Bybelse teologie' bedoel word nie. Die vrae wat aan die orde kom, is onder andere: Bevat die Bybel so 'n teologie? Is teologie net die resultaat op grond van Bybelse refleksie? In watter mate is Bybelse teologie die resultaat van eksegetiese werksaamheid? Kan daar enigsins sprake wees van iets soos 'die Bybelse teologie'? Die veronderstelling was dat dogmatiese teologie gegrond moes word op die resultate van sodanige 'Bybelse teologie'. Die kritiek is steeds geldig dat dogmatiese teologie in die meeste gevalle funksioneer met losstaande uitsprake in die Skrif wat as bewysplase daarvoor moet dien. Alhoewel die kerklike leer (belydenisskrifte) dus nog altyd dien as 'n raamwerk en grens vir teologiese uitsprake, word die relatiewe aard van sulke kerklike uitsprake ook al hoe duideliker. Daar sal toegegee moet word dat die gevarieerdheid van Bybelse teologie dikwels 'n verwarrende beeld kan skep vir 'n dogmatikus. Dogmatiese teologie sal wel moet insien dat tekste vir meervoudige interpretasie oop is en dat daar daarom nie sondermeer reglynige antwoorde gevind word wat deurgetrek kan word na dogmatiese teologie nie.

\section{'n Nuwe fase in Hervormde hermeneutiese ondersoek}

Die vroeëre hermeneutiese uitgangspunt by Hervormde teoloë kan beskryf word as grammaties-histories. Dit het uitgegaan van 'n grammaties-letterlike vertolking van die teks voor hande met pogings tot ' $n$ verwysing na historieskulturele agtergronde. 'n Nuwe fase breek aan, wat ingelei word deur professor G.M.M. Pelser (1985; 1987). Hy was daarvoor verantwoordelik dat Rudolf Bultmann se werk in groter besonderheid bestudeer is. Alhoewel die vormhistoriese werk van Bultmann en andere teruggevoer kan word na die laat negentiende, begin twintigste eeu, het die resultate van die vorm-historiese kritiek by teoloë in SuidAfrika eers veel later na vore getree. Dit was aanvanklik die 'verontrustende' gedagtes van Bultmann (1948; kyk Pelser 1987; Malan 2015) oor die ontmitologisering van die Nuwe Testament wat teoloë in Suid-Afrika aan die praat gesit het. Met die bewustheid oor Bultmann se werk wat daarmee geskep is, het ook die groter ontwaking gekom vir vormhistoriese werk (kyk Dibelius 1971) en daarmee saam die wye veld van historiese kritiek (kyk Krentz 1975). Dit het behels dat ' $n$ verdere verfyning van die kritiese lees van tekste in die Nuwe Testament na vore gekom het. Pelser was die eerste werklik kritiese denker in Hervormde teologie.

Die Hervormde teoloog wat die werk oor metodologie verfyn het, is professor A.G. van Aarde. Reeds in 'n referaat gelewer voor die predikantevergadering van die Hervormde Kerk op 17 September 1985 het hy verskeie aspekte van hierdie 'nuwe paradigma' aan die orde gestel. In die gepubliseerde artikel (Van Aarde 1985) word aspekte van die ontwikkeling van Bybelse hermeneutiek verder toegelig. In 'n vroeër stadium is die klem in Bybelse hermeneutiek geplaas op die outeur en sy aanwending van bronne.

In die historiese kritiek is hierdie beklemtoning uitgewerk en het gestalte gekry in bronne- en literêre kritiek, vormkritiek, tradisiekritiek en redaksiekritiek. Die gemeenskaplike uitgangspunt vir die histories-kritiese interpretasie van die Bybel is dat tekste geneties-kousaal verklaar is. Daar is met ander woorde gesoek na kwessies agter die teks wat bygedra het tot die vorming van die teks soos ons dit het. Die fokus was nie op die teks as sodanig of wat immanent voorhande is nie. Betekenis is gevind in die verklaring van die historiese wording van tekste. Bronne- en literêre kritiek het die outeur buite die teks geplaas en sy aanwending van bronne in fokus gebring. Vormkritiek ondersoek die situasie (Sitz im Leben) waarin verskillende tekste geplaas is, wat korreleer met sosiologiese situasies in die vroeë kerk. Tradisiekritiek kyk na die wyse waarop die teks oorgelewer is en of daar vroeëre stadia van oorlewering aangedui kan word. Redaksiekritiek het geworstel met die wyse waarop die redakteur ook as vertolker 'n invloed gehad het op die teks. Alhoewel redaksiekritiek begin neig het na 'n meer teksimmanente interpretasie, het die klem tog meer op die ontwikkeling agter die teks gelê.

Elkeen van hierdie metodes het dus in die oog gehad om iets van die bedoeling van ' $n$ teks te probeer verstaan. Met die ontwikkeling van die teoretiese denke oor wetenskap (epistemologie) het dit duidelik geword dat antwoorde altyd verband hou met die vrae wat gestel word. Elkeen van die metodes het, behalwe hulle sterk punte, ook gelei tot sekere hermeneutiese dwalings: die foutiewe aanname dat die teks verklaar kan word deur te soek na die bedoeling van die outeur (intentional fallacy); die foutiewe aanname dat die teks uit die wordings van die teks verklaar kan word, asof alles in 'n oorsaak-gevolg skema kan pas (genetic fallacy); die dwaling dat die vergelyking met 'n vermeende situasie (bv. 'n liturgiese, kategetiese of apologetiese situasie) in die vroeë kerk 'n verklaring kan bied vir die teks en dan ook en dalk die mees kritiese aspek dat die 'verwysings' in die teks moet klop met die sake buite die teks wat dan ook die waarheidsgehalte van die uitsprake sou bepaal (referential fallacy). 'n Saak sou daarvoor uitgemaak kon word dat elkeen van hierdie metodes uit die vorige een ontwikkel het en 'n poging tot verbetering op die vorige een was.

In 'n volgende fase is die teks self in die middelpunt geplaas. Die doel was om die outonomie van die teks te respekteer. In hierdie teks-immanente metodes, soos byvoorbeeld in die formalisme en strukturalisme, is die klem nie geplaas op die intensie van die outeur of die situasie agter die teks nie, maar op die bedoeling van die teks self. Die gevare wat uit hierdie metode-kompleks geblyk het, was die foutiewe aanname dat 'n mens daarmee op 'n konkrete manier die verstaan van die teks kan raakvat (fallacy of misplaced concreteness); die foutiewe aanname dat ' $n$ mens op grond van die teks kon deurdring tot die gedagtes en gevoelens van die karakters (affective fallacy), maar dan in die besonder ook dat die leser op grond van die 'affek' of indruk wat die teks op die leser gemaak het, 
'n rol kon speel in die bepaling van betekenis-toekenning (kyk Vorster 1984:104-123). Die affek-dwaling het selfs nog in die latere ontwikkeling van leser-respons-kritiek 'n rol gespeel wanneer die rol van die leser te sterk bekemtoon is in die vastelling van die betekenis van die teks (kyk Van Aarde 1985:571).

Enige poging tot die verstaan van die teks het in die loop van die ondersoek uiteengeval in metodes wat met die oog daarop ontwerp is. Elke metode het vraag-spesifiek ontwikkel. Telkens kon dus net by 'n deel van die antwoord uitgekom word. Daar was slegs die antwoorde wat op daardie spesifieke vrae gevolg het. In samehang en op gebalanseerde wyse kan hierdie metode-komplekse wel 'n bydrae lewer tot die verstaan van die teks. Die nederige wete dat die ondersoek nie afgehandel is nie, sal altyd daarmee gepaard gaan.

\section{Die spanning tussen die vertikale en horisontale dimensies}

In die vroeër tyd (saam met die bydraes van Pelser) het die Ou Testamentikus, J.A. Loader (1978), ook 'n wesenlik belangrike bydrae gelewer tot die Hervormde omgang met die Bybel in die algemeen, dus ook hoe dit die Nuwe Testament raak. Hy het veral klem gelê op die fenomenale ontwikkeling in die taalkunde. Dit het ingrypende konsekwensies gehad vir die hantering van literêre produkte. Die Bybel is ook nie anders as 'n literêre produk waar 'n mens met taal besig is nie. Die ontwikkelings in die taalkunde is van belang vir die eksegese van die Bybel, juis omdat die Bybel niks anders is as ' $n$ versameling van geskrewe literêre werke nie (die verskuiwing van hermeneutica sacra na hermeneutica profana). Dit beteken dat ons nie nuwere wetenskaplike inligting oor menslike taal en literêre produkte kan ignoreer nie. Vir die Hervormde benadering tot die Bybel het dit dus ook die implikasie dat ons verantwoordelik is om alle middele en metodes waaroor ons beskik, aan te wend om hierdie menslike geskrifte wat ons in die Bybel vind, te verstaan en uit te lê, al het die Hervormde benadering nooit die standpunt losgelaat dat ons die Woord van God in die Bybel kan vind nie. Dit is dus juis omdat dit vir ons belangrik is om die Bybel enigsins verstaanbaar te kan uitlê, dat ons alle wetenskaplike metodes tot ons beskikking sal aanwend. Die aanvanklike reaksie, ook in die geledere van Hervormde teoloë, was in 'n mate agterdogtig en afwysend. Wanneer 'n teks krities geanaliseer word met gewone letterkundige metodes is daar gevrees dat die enigheid, uniekheid van die Bybel aangetas word en dat die gesag van die Skrif ook in die gedrang kan kom. Hierdie reaksie was vreemd in 'n teologiese verwysingsraamwerk wat so sterk beïnvloed is deur die teologie van Barth waar die waardering vir die menslike kant van die Bybel uiteraard die gevolg sou hê dat dit oop moes wees vir die kritiese wetenskap (kyk Barr 1961).

Teoloë het ook die konsekwensies wat vir die eksegese uit die taalkunde afgelei is, soms as strukturalisme beskou. Dit het gebeur omdat die struktuur van taal in literêre werke belangrik geword het ook in die lig van insigte wat uit die nuwere linguistiek na vore gekom het. Nog een van die misverstande wat rondom hierdie nuwere ontwikkeling ontstaan het, is dat hierdie metode die alleenreg sou opeis om as die korrekte een te geld. Die teendeel is eintlik waar, naamlik dat hierdie benaderingswyse juis die pluraliteit van metodes al hoe sterker na vore gebring het (opkoms en ontwikkeling van die historiese kritiek as 'n metodekompleks). Hierdie nuwe aanpak het ook ingrypende gevolge gehad vir die wyse waarop die Ou Testament in verhouding tot die Nuwe Testament vertolk en opgeneem is. Die begrip het duidelik na vore gekom dat die ou skema van belofte-vervulling nie reg laat geskied het aan die uitleg van die Ou Testament in eie konteks nie. Die Nuwe Testament het Ou-Testamentiese sitate meermale terugskouend opgeneem om iets oor die Christus-gebeure te kon bevestig. Loader (1978:17) stel dit sterk: 'Die Nuwe Testament gebruik die Oue dikwels arbitrêr. Dit gee egter geen vrypas vir die eksegese van die Nuwe Testament nie'.

Die een insig van die semantiek wat uiters vormend was, is dat 'n woord nie 'n wortelbetekenis (Grundbedeutung) het nie, maar betekenis kry in konteks. Dit het vanuit die taalkunde 'n ander aksent na vore gebring in ons verstaan van die teks en die taal in die teks (kyk Louw 1976; Van Aarde 1978:4248). Dit het veral die saak bekemtoon dat woorde in sinne, paragrawe en selfs wyer vanuit die konteks betekenis kry. En omdat taal altyd die kultuurproduk van mense is wat vanuit hulle eie konteks en verwysingsaamwerk aan woorde bepaalde betekenisse 'toeken', het die bewustheid gegroei dat die waardes en lewensbeskoulike kwessies van Bybelse tye nader en dieper bestudeer moes word (kyk Van Staden \& Van Aarde 1991:55-87).

'Teologiese besinning in die Reformatoriese tradisie gaan bewustelik van die primaat van die teks uit. Dit beteken dat die Bybel as ' $n$ versameling religieuse tekste die grondslag van die teologie vorm. Dit is nie slegs 'n konfessionele standpunt nie, maar ook'n epistemologiese en hermeneutiese een' (Van Staden 2013:3). Vanuit hierdie uitgangspunt bespreek Van Staden (2013) die aard van narratiewe tekste. Bybelwetenskaplikes is meestal taamlik lugtig vir dogma. Die rede daarvoor is dat die teologiegeskiedenis laat blyk het dat dogma dikwels ervaar is as die grootste bedreiging vir die vryheid in die Bybelwetenskappe (kyk Pelser 1985:346349). Loader (1978:3) het reeds aangetoon dat literêre teorie en die daaruit voortspruitende teksimmanente eksegese as bedreigend ervaar is. Hy het ook duidelik aangetoon dat daar geen aansprake was dat hierdie die enigste eksegetiese pad sou wees nie.

By die uitwerk van die pluraliteit van metodes waarmee 'n eksegeet die teks benader, kan dit nie anders as dat die kwessie van vooronderstellings ook van nader beskou moet word nie. Wanneer dit gaan oor die rol van eksegese en dogmatiek is dit nodig dat daar in Reformatoriese verband duidelik gesê moet word:

Eerstens is die belydenis dat ons in die Bybel met Gods woord te doen het, nie 'n towersleutel vir interpretasie nie. Die menslike kant van die Bybel maak dat ons ons moet oriënteer aan die feit 
dat ons met gewone literêre produkte te doen het. Dit beteken dat ons nie van 'n teologiese voorveronderstelling as model vir die eksegese mag uitgaan nie ... Dit beteken verder dat die eksegese nie vanuit die dogmatiek beoefen mag word nie, maar omgekeerd moet die dogmatiek wel op grond van die eksegese beoefen word. (Loader 1978:6)

Van Staden toon ook aan dat een van die gevolge van teksimmanente eksegese was dat dit sekere foutiewe aannames in 'n bestaande eksegeties-hermeneutiese proses ontbloot het. Dit was waarskynlik een van die faktore wat aanleiding gegee het tot die weerstand teen die 'nuwe' luister na die teks. 'n Opmerking deur 'n Hervormde dogmatikus Velthuysen (1984:84; kyk Velthuysen 1985a:364-371) is in hierdie opsig ook belangrik, naamlik dat belydenisskrifte dokumente is wat ook in ' $n$ bepaalde situasie ontstaan het. Daarom kan belydenisskrifte ook nie as tydlose dokumente voorgehou word nie. Van Staden kom tot die gevolgtrekking dat die wyse waarop die Hervormde teologie die begrip 'Bybels-Reformatories' implementeer by sekere teoloë en groepe ongelukkig die uitwerking het dat:

die begrip as 'n dogmaties-ideologiese a-priori ingespan word, as 'n soort sjibbolet by die toets vir regsinnigheid. Dit is in stryd met die Reformatorese vryheid wat die Hervormde teologie deurgaans vir sy teoloë en akademici gehandhaaf het. (2013:9)

Dit gaan in 'n artikel van prof. Y. Dreyer onderliggend oor die soeke na eenheid te midde van die werklikheid van baie verskillende vertolkings van die Skrif. Die artikel dui aan hoe die begrip sola Scriptura tog wel in hierdie soeke na koers van betekenis kan wees. Die probleem is waarskynlik hierin te soek dat die Skrif dikwels so geïnterpreteer word 'dat dit lei tot verwarring, vervreemding en uitsluiting, eerder as om te verenig, te akkommodeer en te verras' (Dreyer 2015:2). Die Reformatoriese beginsel van sola Scriptura het uiteraard nie daarin geslaag om eenheid te bewerkstellig nie, al geld dit baie wyd as uitgangspunt. Teoloë wat saamstem dat die Skrif gesag het, se paaie loop uiteen wanneer daar gekyk word na hoé die Skrif verstaan word. Sommige soek dit in 'n letterlike vertolking van wat geskryf staan en werk amper asof dit interpretasieloos verstaan kan word. Ons is lankal by die punt verby dat ons kan dink interpretasieloosheid en selfs vooronderstellingloosheid vir die uitleg van die Skrif moontlik is. Die klem het verskuif sodat die gesag van die Skrif nie in die letter lê nie, maar in die persoon van Jesus Christus. Yolanda Dreyer (2015) stel dit soos volg:

Die persoon is nie tasbaar [teenwoordig], maklik definieerbaar of interpreteerbaar nie. Hy word hoogstens sigbaar deur die Skrif. Die beste waarop Christen-gelowiges kan hoop, is om iets van sy saak raak te sien soos wat dit uit die Skrif straal. Geloofsgemeenskappe kan hoogstens saam probeer identifiseer wat sentraal is tot die Jesus-saak en dan probeer om te lewe in die gees van wat Jesus geleer en geleef het. (bl. 2)

In so 'n verstaan van die kern van Skrif-alleen uitsprake kan gesoek word na 'n verstaansriglyn wat ons nader aan eenheid kan bring.

Sedert die opkoms en ontwikkeling van historiese kritiek weet ons al duideliker dat daar afstand is tussen die wêreld van die teks en elke geslag lesers wat volg. Die verstaanproses van die teks is telkens nodig om 'n brug te bou tussen die teks en die lesers. Dreyer (2015:3; vgl Pokorný 2011:178-180) stel dit soos volg:

Die verstaansproses behels 'n dubbele beweging, naamlik van die teks in verhouding tot die wêreld van die teks en die verstaan van die hedendaagse lesers in verhouding tot die wêreld. Die teks is die norm. Die interpretasie moet aan die teks getoets word. Die taak van interpretasie is om gemeenskaplikhede te soek sodat ' $n$ verband tussen die twee wêrelde gevind kan word.

Hans-Georg Gadamer ([1960] 2010) noem dit 'n versmelting van horisonne. In die soeke na die moontlike brug wat in sola Scriptura gevind kan word, wys Dreyer (2015) op die volgende:

As wat God in Jesus Christus gedoen het, die 'Skrifbeginsel' is, dan is Jesus, en nie die Skrif nie, die openbaring van God ... Die Christelike geloof is nie ' $n$ godsdiens van 'n boek nie, maar van 'n persoon, die opgestane Heer. (bl. 4)

Daarom verwys sy na die Jesus-saak wat as die kern van hierdie Skrifbeginsel kan geld. In die mate waarin mense mekaar dus kan vind binne die raamwerk van hierdie Skrifbeginsel, naamlik dat dit die Jesus-saak is, kan die begrip sola Scriptura ook as die brugbouer funksioneer vir die verstaan van die boodskap van die Skrif.

\section{Verstaansmodelle as bakens}

Die hele proses van kritiese denke soos wat dit na vore gekom het in die historiese kritiek het sy uitlopers gehad na verskillende modelle wat ontwikkel is vir die verstaan van die teks en met verwysing na die wêreld waarin die verstaan van die teks geaktualiseer moet word. Dit het begin met literêre teorie: wat is ' $n$ teks? Dit het gelei tot ' $n$ verskerping van die verstaan dat 'n teks ook ideologies gelaai is. Daarom was dit nodig om 'n hermeneutiek van suspisie te ontwikkel. Momente van hierdie hermeneutiek van suspisie was reeds teenwoordig in literêre studies waaraan die Bybel ook onderwerp is. Dit het onder andere skerp na vore gekom in feministiese teorieë en bevrydingsteologieë. Die konsep postmoderniteit is later ontwikkel en verfyn om die fenomeen te beskryf dat daar na modernisme en positivisme ' $n$ ander benaderingswyse na vore gekom het tot die lees en verstaan van tekste, maar dan veral oor die relevansie van hierdie boodskap in die lewens van mense.

Die riglyn(e) vir Hervormde hermeneutiek wou van die begin af rekening hou met ' $n$ wetenskaplike benadering tot tekste en die uitleg daarvan. Dit het vanselfsprekend geword in enige wetenskaplike besinning dat daar duidelikheid gekry moet word oor teorieë, modelle en metodes. Omdat die Bybel as literatuur ook plek gevind het in die geskiedenis met die opkoms van 'n historiese bewussyn vanaf die Reformasie, geld dieselfde vereistes vir die wetenskaplike ondersoek van die Bybel, ook met die wete dat alle teorieë, modelle en metodes voorafgegaan word deur bepaalde aannames - of hulle uitgespel is of nie. Ons het dit aan Rudolf 
Bultmann te danke dat dit ook in enige Bybelondersoek en interpretasie as aksioma geld dat vooronderstellinglose eksegese nie moontlik is nie. Die positiewe keerkant stel dus dat eksegete in hulle uitleg van die Skrif ook gelei en gerig word deur die vooronderstellings van hul eie tyd en wetenskapskring (soos in enige wetenskaplike onderneming).

Ek is van mening dat dit met reg gestel kan word dat die ontwikkelings van die afgelope vyf dekades in die kring van Hervormde Nuwe Testament-uitleg en teologie-beoefening in die algemeen hieroor gegaan het dat dit in die kenproses nodig was om die vooronderstellings in alle teorieë, modelle en metodes uit te spel.

Die bewustheid het ook gegroei dat ons nie kon volstaan met die histories-kritiese modelle nie. In alle wetenskaplike ondersoeke kom daar vooronderstellings na vore vanuit die sosiologiese, antropologiese en psigologiese verwysingsraamwerke van die ondersoekers. Dit het duidelik geword dat alle kennis sosiaal gekondisioneer en perspektiwies van aard is (Berger \& Luckmann 1967:3). Dit raak al drie aspekte wat in die interpretasieproses onderskei kan word, naamlik die interpreteerder, die saak (teks) wat geïnterpreteer word en die weg waarlangs (metodes, modelle) dieinterpretasie onderneem word. Waar vroeër gestel kon word: 'Hierdie pendule objektief/subjektief vorm die hart van wat as 'n hermeneutiese benadering tot teologie-beoefening beskryf word' (Van Aarde \& Dreyer 2011:2), het dit al duideliker geword dat die sosiale kondisionering vir alle kennis geld, vir die interpreteerder, maar net so ook vir die skrywers van tekste sowel as vir die metodes wat gebruik word. Totale objektiwiteit het as moontlikheid verdwyn.

Dit is begryplik dat die vorige opvattings ook die vraag oor wat waarheid is, in gedrang gebring het. Daar was nog altyd die dwingende opvatting dat waarheid objektief moet wees. Waarheid was daarvan afhanklik dat 'n saak weergegee is presies soos wat dit werklik is. Dit moes dus objektief vasstelbaar kon wees. Een van die wegwysers op ons pad was die Rapport van die Gereformeerde Kerken Nederland wat in 1981 verskyn het. Dit verteenwoordig 'n besinning oor die gesag van die Bybel met besondere verwysing na wat as waarheid beskou kan word. Hieruit het duidelik na vore gekom dat die waarheid sou moes voortkom uit twee dele, naamlik die objektiewe buite die mens (waarheid as rigsnoer) en die subjektiewe in die mens (waarheid as worsteling en inset van die mens). Maar indien dit net weer sou neerkom op die teenstelling objektief teenoor subjektief, is daar nie gevorder nie. Die gevolgtrekking was: waarheid is nie sonder meer iets buite die mens nie, maar ook nie slegs die inset van die subjektiewe mens nie. Dit is ook nie 'n optelsom van die twee nie. Waarheid word telkens ontdek binne die betrokkenheid van 'n ondersoeker by die saak wat ondersoek word. Waarheid kan binne hierdie relasie van ' $n$ mens by dit wat ondersoek word, geken word. Ons het dus te make met 'n relasionele waarheidsbegrip (kyk Velthuysen 1985b:108113). Beide ondersoeker en teks (in hierdie geval) het hulle eie sosiale staanplek en vooronderstellings wat ter sake is.
Dit was uiteraard nie alles totaal nuwe insigte nie, maar dit het ingrypend bygedra tot ons omgang met en verstaan van tekste. Daar was lankal die bewussyn dat daar afstand is tussen die lesers van antieke tekste (soos die Bybel) en die kontekste van die skrywers van daardie tekste. Dit kon nie uitsluitlik histories ondersoek word nie. Daar moes rekening gehou word met faktore op al drie vlakke van so'n ondersoek, naamlik die (hedendaagse) leser, die skrywers en hulle wêreld, en die uitlegmetodes wat benut word. Die historiese benadering tot eksegese en teologie het ontwikkel tot 'n multidissiplinêre onderneming waarin kritiese teksteorieë oor die literêre ontwikkeling van tekste in verband gebring word met die kulturele en sosiale konteks waarin tekste ontstaan het en verwyder van waaruit riglyne afgelei kan word om hulle in vervang met hedendaagse tye te interpreteer. Hierdie komplementêre aanpak het bekend geword as die sosiaal-wetenskaplike kritiek. Elliott (1993:7) beskryf dit onder andere as:

the manner in which this textual communication was both a reflection of and a response to a specific social and cultural context - that is, how it was designed to serve as an effective vehicle of social interaction and an instrument of social as well as literary and theological consequence (kyk ook Joubert 1991:39_ 54, vir hoe dit by teoloë van die Hervormde Kerk gestalte gekry het; kyk ook Van Staden \& Van Aarde 1991:55-87).

Professor E. van Eck het in sy werk oor gelykenisnavorsing ook aangetoon hoe noodsaaklik dit is om hierdie tekste te ondersoek met sensitiwiteit vir die verskil tussen literêre en sosiale kontekste. Dit verg ook die nodige aandag vir die kulturele raamwerk en ervarings van die aanvanklike hoorders. Die sosiaal-wetenskaplike benadering werp lig op die sosiale realia wat dikwels implisiet agter die tekste lê. Dit bring ons vir ons verstaan daarvan nader aan 'die sosiokulturele, politieke, godsdienstige en ekonomiese realiteite van die wêreld waarin Jesus en die aanvanklike hoorders geleef het'. Dieselfde geld ook wat sy bydrae tot die verstaan van die huwelik betref soos vergestalt in die Ou en Nuwe Testament (Van Eck 2015:3).

In die kontekstuele teologie is die implikasies van sosiale gekondisioneerdheid verder verfyn. Die Bybel is bewustelik ook vanuit en in terme van die sosiale omstandighede van die Bybelskrywers en van die hedendaagse leser geïnterpreteer. Hierdie aangeleentheid het nie altyd vroeër in die hermeneutiek uitdruklik aandag gekry nie. Yolanda Dreyer (1998) stel dit soos volg:

In die kontekstuele hermeneutiek word uitdruklik aanvaar dat die huidige leser van die Bybel die teks benader vanuit sy of haar kontemporêre ervaring. Spesifieke ekologiese, kulturele en politieke omstandighede speel in op die lees van die Bybel. In die bevrydingsteologie is dit die ekonomies behoeftige en die polities onderdrukte wat die uitgangspunt in die hermeneutiek is. Die feministiese teologie het die negatiewe ervarings van vroue begin uitlig. (bl. 623)

Sodanige lees van die Bybel het ook doelbewus waardes en magstrukture van daardie wêreld ontbloot. Dit het in die besonder gegaan oor die patriargale agtergrond van die 
Joods-Christelike tradisie. Hierdie Skrifbenadering het tot die gevolgtrekking gekom dat die patriargie en al die negatiewe gevolge daarvan beskou is as historiese inligting in die Bybel en nie teologies nie. Dreyer (1998) stel dit soos volg:

Die tradisie van manlike dominansie en androsentriese diskriminasie word toegeskryf aan sosio-historiese faktore. Diskriminerende maatreëls is aspekte wat kultureel bepaald is en is nie inherent aan menswees nie. Wanneer die praktyk aandui dat die kultuur nie meer in pas is nie, kan die maatreëls hervorm word. (bl. 628)

Hierdie hermeneutiese benadering tot die Skrif is ook betrokke hermeneutiek genoem. Dit het meegebring dat daar bewustelik gekies word vir "n hermeneutiek van suspisie'. Dreyer (1998) beskryf dit soos volg:

Hoewel dit ' $n$ 'hermeneutiek van suspisie' genoem kan word, is dit ' $n$ benadering met ' $n$ positiewe doelwit. Die tradisie (in die Bybel en in die kerk) word geag as die moeite werd om te rehabiliteer. Op 'n gematigde wyse word aangedui dat die situasie van androsentrisme en negatiewe ervaring van vroue nie langer gehandhaaf kan word nie en dat die postmoderne wêreld verandering noodsaaklik maak. (bl. 628)

In postmoderne epistemologie word die saak van pluraliteit sterk beklemtoon. Dit raak nie net samelewingsteorieë nie, maar is ook in die besonder van toepassing op die Skrifbeskouing. Bybelwetenskaplikes het sterk na vore gebring dat daar in die Skrif meerdere tradisies teenwoordig is wat selfs ook teensprekend van aard kan wees. Dit het al na vore gekom in die historiese kritiek wat die aanwesigheid van verskillende bronne, tradisies en oorleweringslae geïdentifiseer het. Een van die belangrike bydraes van die historiese kritiek is dat die eksegeet vanweë die kompleksiteit van sowel die Bybel as die samelewing, nie meer op ' $n$ naïewe fundamentalistiese wyse met die Bybel kan omgaan nie (Dreyer 1998:634).

Die aanvulling van histories-kritiese metodes met aspekte van onder andere die narratologie en sosiaal-wetenskaplike kritiek het 'n verskuiwing in die hermeneutiese gerigtheid gebring. Die verandering in klem het beteken dat daar nie langer net op die historiese verstaan van tekste gefokus kon word nie, maar ook op die resepsie daarvan. Deur middel van die betrokke hermeneutiek word die gesag van die Bybel geillustreer deur die proses van 'n ontmoeting met die verhale in die Bybel. Die relasionele waarheidsbegrip kom ook weer so na vore.

\section{Die proses gaan voort}

In hierdie voëlvlug-artikel kon daar uiteraard maar hoogstens by enkele padtekens iets verneem word oor die koers wat in die Hervormde kring ingeslaan is oor ons verstaansproses van veral die Nuwe Testament. Dit het geblyk dat daar van vroeg af 'n tradisie gevestig is van 'n oop, kritiese of dan wetenskaplike benadering tot die verstaan van tekste soos dit in die Skrif aangebied word. Dit is juis gebore en is gevoed vanuit 'n houding van respek vir die Nuwe Testament. Dit was altyd 'n eerlike en opregte poging om die Skrif in eie reg te laat spreek. Die verklaarde uitgangspunt was nog altyd dat ons in die Skrif/Nuwe Testament met die gesagvolle bron te make het en dat die Woord van God uit so 'n ontmoeting en deurtastende ondersoek tot spreke moes kom. Dit is so aangepak welwetend dat dit'n kerklike uitgangspunt is wat van subjektiwiteit beskuldig kan word. Dit is apriories die vertrekpunt en daar is geen manier waarop dit 'wetenskaplik' teenoor ander openbaringsbronne 'bewys' kan word nie.

Al was dit deel van die groter prentjie waarbinne ons paradigma as subjektief aangedui kan word, het daar binne die kleiner kring van teologie-beoefening vir lank die ideaal bly voorbestaan dat die teks 'n objektiewe antwoord gebied het in verband met 'die openbaring' wat van buite of van boaf gekom het. Daarom was daar ook bepaalde standpunte wat aangedring het op ' $n$ beklemtoning van wat genoem is die vertikale dimensie van teksverstaan met afwysing van enigiets wat as horisontaal aangedui is. Die menslike inset en die implikasies vir menslike bestaansvrae was genegeer.

Maar as kinders van die kerkhervorming het die gevolge van 'n historiese bewussyn ook deurgewerk in die Hervormde benadering tot die Nuwe Testament. In die voetspore van Luther en ander hervormers het dit begin met vrae oor die kanon. Dit het gelei tot die latere standpunt dat die kanon wel de facto afgesluit is, maar de iure oop beskou word. Die historiese-kritiek as benaderingswyse (paradigma) het gelei tot die verfyning van verskeie metodologiese ontwikkelings in die hermeneutiese benadering van die teks(te) soos ons dit vind in die Nuwe Testament.

Dit was die spore wat ek in hierdie artikel kursories aangedui het. Enige leser van die artikels wat ons in die HTS vind, sal die gesindheid en werkwyse vind van Hervormde en ander teoloë wat in die HTS gepubliseer is, van ernstige en diepgaande worsteling om die betekenis van die tekste te ontsluit. Hierdie verstaansproses is nie afgesluit in 'n geslote proses nie. Dit sal voortgaan. En al word daar vanuit verskeie hoeke vrae aan die teks gestel, gaan dit altyd gepaard met die wete dat ons uiteindelik die aangesprokenes is wat deur die teks opgeroep word tot beslissings vir die lewe:

Vir Luther is die Skrif nie 'onskuldig' of volmaak nie. Dit behoort nie geromantiseer of gemistifiseer te word nie. Dit gebeur soms in geloofsgemeenskappe wat hulleself as 'Bybels' beskou. Die gevolg is dikwels dat die wat die Bybel 'uit respek' teen kritiese perspektiewe wil verdedig, konflikte in die Bybel self en opponerende elemente wat hulle ongemaklik maak, harmonieer en wegverklaar. In werklikheid kom dit dan neer op 'n verwringing van sowel die werklikheid as die waarheid van die Skrif. Daar word beheer geneem oor die Skrif en dit word vervorm tot iets wat dit nie is nie. Dit getuig nie van respek nie. Die Skrif word benader vanuit ' $n$ vooraf bepaalde ideologie oor die Bybel en word vanuit daardie perspektief geïnterpreteer. (Dreyer 2015:6)

Bybellesers raak bewustelik betrokke by wat hulle lees en die waardes wat hulle so ontdek, lei hulle tot selfinsig, selfkritiek en beslissings. Dit word beskryf as 'n epistemologie van deelname. Dit beteken nie dat hier 
sprake is van 'n simmetriese ontmoeting asof mense besluit wat aanvaarbaar is of nie. Dit bly steeds die waardes wat in die Bybel ontdek word, wat 'n appèl tot mense rig (Dreyer 1998:634).

Ek is van mening dat in nederigheid gestel kan word dat hierdie soeke na verstaan in die hermeneutiese aanpak van die Hervormde Kerk voortkom op grond van die geloof en 'n liefde vir die Woord. Maar dan in die besonder vir die Woord wat mens geword het.

\section{Erkenning \\ Mededingende belange}

Die outeur verklaar dat hy geen finansiële of persoonlike verbintenis het met enige party wat hom nadelig kon beïnvloed het in die skryf van hierdie artikel nie.

\section{Literatuurverwysings}

Barr, J., 1961, The semantics of biblical language, Oxford University Press, Oxford.

Berger, P. \& Luckmann, T., 1967, The social construction of reality, Penguin, Harmondsworth, UK

Boers, H., 1979, What is New Testament theology, Fortress, Philadelphia, PA.

Brunner, E., [1938] 1963, Wahrheit als Begegnung, Theologischer Verlag Zürich, Zürich.

Bultmann, R., 1948, 'Neues Testament und Mythologie: Das Problem der Entmythologisierung der neutestamentlichen Verkündigung', in H.W. Bartsch (Hrsg), Kerygma und Mythos: Ein theologisches Gespräch, pp. 15-53, Rein \& (Hrsg), Kerygma und Mythos: Ein theologisch
Heidricher-evangelischer Verlag, Hamburg.

Bybel met Verklarende Aantekeninge, 1958, Verenigde Protestantse Uitgewers, Kaapstad.

Dibelius, M., 1971, Die Formgeschichte des Evangeliums, Mohr, Tübingen.

Dreyer, Y., 1998, 'Feministiese hermeneutiek as kritiese teorie', HTS Teologiese Studies 54(3\&4), 623-651. https://doi.org/10.4102/hts.v54i3/4.1437

Dreyer, Y., 2015, 'Die ontmoeting van wêrelde en die beginsel van sola Scriptura', HTS Teologiese Studies/Theological Studies 71(3), Art. \#3045, 1-7. https://doi.org/ 10.4102/hts.v71i3.3045

Elliott, J.H., 1993, What is social-scientific criticism? Fortress Press, Minneapolis, $\mathrm{MN}$.

Engelbrecht, B.J., 1986, 'Wat is die reg en die vryheid van die eksegeet?', HTS Teologiese Studies 42(3), 485-501. https://doi.org/10.4102/hts.v42i3.2179

Gabler, J.P., 1831, Kleiner theologische Schriften, Stettinische Buchhandlung, Ulm.

Gadamer, H.-G., [1960] 2010, Gesammelte Werke: Hermeneutik: Wahrheit und Methode, Band 1., Grundzüge einer philosophischen Hermeneutik, Mohr Siebeck, Tübingen.
Gereformeerde Kerken Nederland, 1981, God met ons: Over de aard van het Schriftgezag, Tijl Libertas, Utrecht.

Geyser, P.A., 1989, 'Prof Dr FJ van Zyl se Skrifbeskouing', HTS Theologiese Studies 45(2), 253-262. https://doi.org/10.4102/hts.v45i2.2254

Greyvenstein, J.H.J.A., 1944, 'Verklaring insake "'n Afrikaans Bybelverklaring"', HTS Teologiese Studies 1(3), 79-99. https://doi.org/10.4102/hts.v1i3.3316

Joubert, S.J., 1991, " $n$ Verruimde invalshoek tot die verlede? Die sosiaal-wetenskaplike benadering tot die Nuwe Testament', HTS Teologiese Studies 47(1), 39-54. https://doi.org/10.4102/hts.v47i1.2351

Krentz, E., 1975, The historical-critical method, Fortress, Philadephia, PA.

Loader, J.A., 1978, 'Gedagtes oor gekontroleerde eksegese', HTS Teologiese Studies $34(1 \& 2), 1-40$.

Louw, J.P., 1976, Semantiek van Nuwe Testamentiese Grieks, Beta Pers, Pretoria.

Malan, G.J., 2015, 'Die Nuwe Testament en mitologie: Die probleem van die ontmitologisering van die Nuwe-Testamentiese verkondiging. Bultmann se 1941 opstel weer bekyk', HTS Teologiese Studies/Theological Studies 71(3), Art. \#2757, 1-8. https://doi.org/10.4102/hts.v71i3.2757

Pelser, G.M.M., 1985, 'Die verhouding Bybelse teologie en dogmatiese teologie', HTS Teologiese Studies 41(3), 339-350. https://doi.org/10.4102/hts.v41i3.2142

Pelser, G.M.M., 1987, 'Die ontmitologiseringsprogram van Rudolf Bultmann', HTS Teologiese Studies 43(1\&2), 162-191.

Pokorný, P., 2011, Hermeneutics as a theory of understanding, transl. A. BrysonGustová, Eerdmans, Grand Rapids, MI.

Van Aarde, A.G., 1978, 'Moderne semantiek en formele homiletiek', HTS Teologiese Studies 34(1\&2), 41-56. https://doi.org/10.4102/hts.v41i4.2172

Van Aarde, A.G., 1985, 'Skrifgebruik: Hermeneutiese riglyne', HTS Teologiese Studies 41(4), 547-578.

Van Aarde, A.G. \& Dreyer, T.F.J., 2011, 'Die pendule subjektiwiteit-objektiwiteit in die teologie van Theuns Dreyer-'n dialoog', HTS Teologiese Studies 67(3), Art. \#1172, 1-11. https://doi.org/10.4102/hts.v67i3.1172

Van der Merwe, P.J., 1989, 'Professor Doktor F.J. van Zyl as mens, kerkman en godsdiensfilosoof', HTS Teologiese Studies 45(2), 231-252. https://doi. org/10.4102/hts.v45i2.2253

Van Eck, E., 2015, 'Gelykenisse van Jesus: Allegorieë of simbole van sosiale transformasie', HTS Teologiese Studies 71(3), Art. \#3030, 1-10. https://doi.org/ 10.4102/hts.v71i3.3030

Van Staden, P., 2013, 'Bakens, drumpels en webbe: (Hervormde) Teologie as kreatiewe onderneming', HTS Teologiese Studie 69(1), Art.\#1981, 1-10. https://doi.org/ 10.4102/hts.v69i1.1981

Van Staden, P.J. \& Van Aarde, A.G., 1991, 'Social description or social-scientific interpretation: Survey of modern scholarship', HTS Teologiese Studies 47(1), 55-87. https://doi.org/10.4102/hts.v47i1.2353

Van Zyl, F.J., 1944a, 'Die Skrifbeskouing van Karl Barth', HTS Theologiese Studies 1(3), 126-135. https://doi.org/10.4102/hts.v1i3.3320

Van Zyl, F.J., 1944b, 'Ken jy die Bybel?', Die Hervormer, April, pp. 6-7.

Velthuysen, G.C., 1984, 'Skrifbeskouing in die Nederlandse Geloofsbelydenis', HTS Teologiese Studies 40(4), 84-92.

Velthuysen, G.C., 1985a, 'Wat is die woord van God - Skrif, belydenis, prediking?', HTS Teologiese Studies 41(3), 364-371. https://doi.org/10.4102/hts.v41i3.2146

Velthuysen, G.C., 1985b, 'Die betekenis van die relasionele waarheidsbegrip vir die Skrifbeskouing', HTS Teologiese Studies 41(1), 108-113.

Vorster, W.S., 1984, 'The historical paradigm: Its possibilities and limitations', Neotestamentica 18, 104-123. 